\title{
Difference Level of Professionalism and Quality of Learning Process Based On Undergraduate Education Teacher Background
}

\author{
Jaja Kustija \\ Electrical Engineering Education Department, Indonesia University of Education, \\ Jl. Dr. Setiabudhi 227, Bandung 40154, West Java, INDONESIA \\ j.kustija@gmail.com
}

\begin{abstract}
This research aims to know the different level of professionalism competencies of vocational teacher's educational backgrounds, thus vary as follows: Bachelor of technical education (S.Pd), Bachelor of applied science (S.ST), and Bachelor of Engineering (ST). The competencies include pedagogic competence, social competence, personal competence, and professional competence. Research method is descriptive quantitative with comparative design. The results of this study show Bachelor of technical education (S.Pd) have the highest level professionalism and quality of learning process than those educational backgrounds at certain significance. Implications of this research is expected to provide input for planning of vocational teacher candidates of electronics and electrical at vocational schools that most suitable in West Java and the contribution from government for improve vocational teacher professionalism.
\end{abstract}

Index Terms - teacher educational backgrounds, competencies, profesionalism, quality learning.

\section{Introduction}

Professional teacher competency by law No. 14 of 2005 about Teachers and Lecturers on Chapter IV section I article 10 paragraph 1 [1][2][3][4][5][6] are described that the competence of teachers includes pedagogical competence, personal competence, social competence, and professional competence [7][8][9]. In fact, there are many teachers who teach without planning, do not use appropriate methods, and do not invite the students actively involved in learning, assume students have the same learning style and treated equally, then conduct the evaluation without guidance.

Personality competence is the ability of a solid personality, noble, wise and authoritative, as well as being role models for students [7]. In reality there are teachers who are not disciplined in administration, keeping time, and not become a role model for the students in the teachings of his religion. Based on the concept and reality, there is still a gap between the ideal theory and the reality on the ground. In reality, there are teachers who do not care and guiding the students in terms of social competence, just assume the students live in the community as a personal not social [7][8].

The reality in the field there are still teachers who lack of proper control of the subject matter which are comunicated to student. Based on the gap between the theoretical ideal and the reality that exist in the real class, so it is necessary to make a research whether teacher's educational background influence on the professional competence of the teacher. Professionalism of teachers is influenced by some factors such as educational background, teaching experience, motivation, training, experience, personality, social class and age, in this research, only discovered the difference level of professionalism of teachers vocational program of electricity and electronics engineering in West Java based on background undergraduate education, the Bachelor of Technical Education (S.Pd), Bachelor of Applied Science (S.ST), and Bachelor of Engineering (ST)[10][11].

\section{Method}

The research method used is descriptive quantitative with comparative design [12][13].

\section{Result and Discussion}

This study resulted in 3 main things, namely: (1) determine whether there are differences in the level of professionalism of teachers' vocational course of study of electronics and electricity expertise based undergraduate education background (S.Pd, ST, S.ST), and find the best among the three (S.Pd, ST, S.ST); (2) determine whether there are differences in the quality of vocational teachers learning skills study programs based electronics and electricity undergraduate education background (S.Pd, ST, S.ST), and find the best among the three (S.Pd, ST, S.ST); (3) determine the effect of the level of professionalism of teachers' vocational course of study of electronics and electricity expertise on the quality of the learning process.

Knowing the difference in the level of professionalism of teachers, vocational study program based on the expertise of electronics and electricity undergraduate education background (S.Pd, ST, S.ST), and find the best among the three (S.Pd, ST, S.ST).

Based on the results of statistical tests, it found that the Post Hoc Test for the educational background of teachers in the professionalism of teachers there is a difference at the $85 \%$ confidence level or $(\alpha=0.15)$ and educational background of the teacher which is the most highly rated is professional educational background S.Pd Engineering.

Based on the results of data processing obtained average value of the professionalism of teachers surveyed by 
self-evaluation questionnaire of the teacher in the form of interval data has an average order value S.Pd $=99.07$, S.ST $=96.84, \mathrm{ST}=93.79$. Data assessment of teacher professionalism self-evaluation and top assement can be shown in Figure 1.

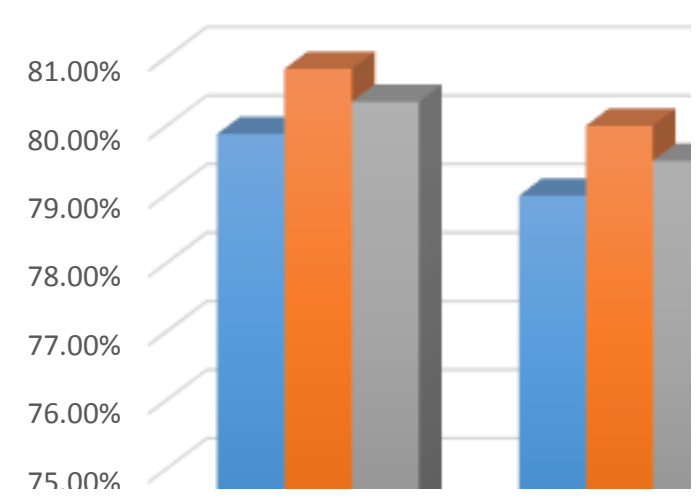

Fig. 1 Graph Professional Teacher Self Evaluation, Rating Tops, Combined.

Knowing the difference in the quality of vocational teachers learning skills Study programs based electronics and electricity undergraduate education background (S.Pd, ST, S.ST), and find the best among the three (S.Pd, ST, S.ST).

Based on the results of statistical tests, it was found that the Post Hoc Test for the educational background of teachers on the quality of the learning process, there is a difference at the $90 \%$ confidence level or $(\alpha=0.10)$ and the best educational background for the quality of the learning process is the educational background of S.Pd Engineering.

Based on the results of data processing obtained average value of the professionalism of teachers surveyed by self-evaluation questionnaire of the teacher in the form of interval data has an average order value S.Pd $=104.26$, S.ST $=101.48, \mathrm{ST}=97.74$. Data quality of the learning process of self-evaluation and top assessment can shown in figure 2 .

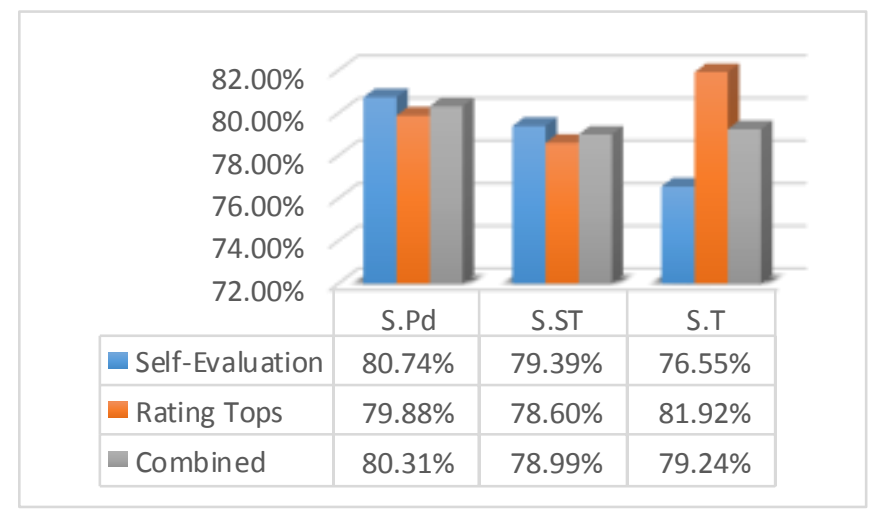

Fig. 2 Graph Learning Quality Process Self Evaluation, Rating Tops, Combined.

Determine the influence of professionalism level of vocational school teachers in course of study of electronics and electricity expertise on the quality of the learning process.
Based on the results of statistical tests, the score obtained Pearson correlation of 0.797 at 0.01 level of significance 2 tailed test. These results suggest that the professionalism of vocational skills teachers in courses electronics and electricity in West Java has a fairly high positive correlation to the quality of the learning process means, $63.5 \%$ the quality of the learning process is determined by the professionalism of teacher expertise in electronics and electricity engineering in West Java.

Discussion of differences in the level of professionalism of vocational study teachers based on the expertise of electronics and electricity with undergraduate education background (S.Pd, ST, S.ST), and determining the best among the three (S.Pd, ST, S.ST).

The level of teachers professionalism is determined by four competencies required are: pedagogical, social competence, personal competence, and academic competence/professional competence (content vocational/productive skills content)[8][10][11]. In fact Bachelor of Technical Education has been prepared to be a productive teacher in SMK and comes with basic science subjects (mathematics, physics), basic knowledge of electrical engineering (electromagnetic fields, electric circuits, measurement of electrical quantities, basic control systems, numerical analysis, basic programming and other) and vocational courses (skills courses into core competence as teachers of vocational field workers), in addition to the teaching ability, they get also the provision of educational sciences and teaching (Learning Methods, Basis Education, Lesson Planning, Evaluation of Learning, Development of Students, Research Methods and others)[14][15][16].

Based on the assessment results of the existing curriculum and study of several theories, the analysis of results obtained Bachelor of Engineering prepared for designers, researchers, and developers (engineering) in field of engineering [17].

Based on the results of existing curriculum, that was prepared as a Bachelor of Applied Sciences in the field of technical professionals who apply the research results in the field of science and technology with the ability to work is a mainstay of his main skill.

From the above description is desirable educational background Bachelor of Technical Education has a level of professionalism in the field because it has been prepared in such a way as to handle field work[18].

Based on the results of the research that described in the Educational Studies Program in Bachelor of Electrical Engineering who made Engineering Education, to prepare professional teachers we should conduct more in-depth research to plan, carry out, and evaluate a sustainable form of vocational teacher education program to have candidates who study Electronics and Electricity skills.

Attempts to self-professionalization of vocational teachers skills in electronics and electricity courses, among others, by doing good improvement pedagogic competence, social competence, personal competence and professional competence (vocational content).

Efforts to improve the competency which can be applied are; formed the course group with the same skill, organize the seminars either as a presenter or participant, reviewing literature from books or the Internet, do a test in the workshop and in the laboratory, making innovation work 
with students that are beneficial to the community, working with the government to explore the potential in the surrounding region to develop a curriculum (Curriculum Education Unit).

The results of study at some vocational schools in West Java in general courses that teach skills in electronics and electricity in West Java, they do not have experience working in the industry, but in general the school has partnerships with several industries to entrust their students for internship, one of the vocational which has a partnership with industry to provide work experience is a teacher at SMK 1 Cimahi industry.

Competency of vocational teachers should include competency areas which taught, scientific philosophy, scientific development, and the higher analysis than students' competence standard so it can become learning resources and learning experiences. Internships in the industry also must achieve good competency standard.

Discussion of the differences in the quality of the learning process of vocational program teachers based on the expertise of electronics and electricity undergraduate education background (S.Pd, ST, S.ST), and determining the best among the three (S.Pd, ST, S.ST)

The quality of the learning process is determined by several factors, there are; the behavior of educators (preparation of lesson plans, implementation of learning, motivating, innovative, creative, fun, selecting appropriate media, respect for diversity of learners), evaluation of appropriate learning, learning outcomes or satisfying outcomes (achievement of competence, valued in the community, working according to the field).

The above results indicate that these factors are also owned by teachers in different backgrounds (Bachelor of Engineering and Bachelor of Applied Science). This can happen because the teacher will develop competence, although formal education scholarship program that they follow are not specifically included in the curriculum which studied.

A review of the research and field studies to obtain a good quality of learning processes in vocational schools different from public schools, the public school teachers prepare their students for a career in the further education system, while vocational high schools should prepare their students for a career in the world, especially to have a good job, its requires vocational competence and professional competence when they work in the world of business and industry. Working experience in business and industry (Industrial Experience) can be grown with cooperation between business and industry, schools and government.

\section{Conclusion}

Based on the objectives to be achieved in this study, the conclusions obtained the following results:

- At $\alpha=5 \%$ there is no difference between the professionalism of teacher education background S.Pd, ST, and S.ST.

- At $\alpha=15 \%$ level of teachers professionalism with educational background S.Pd higher than educational background ST teachers and S.ST. The level of professionalism of vocational teachers in electronics and electricity expertise study programs in West Java can be shown in the results of data processing using one-way ANOVA, 3:18 until 3:21 at the table, resulting in the following order: S.Pd $=99.07$, S.ST $=96.84$, ST $=93.79$.

- At $\alpha=5 \%$ there is no difference between the quality of the learning process of teacher with education background S.Pd, ST, and S.ST.

- At $\alpha=10 \%$ the quality of the learning process of vocational teachers in courses electricity and electronics engineering in West Java, teacher with Bachelor of Technical Education background higher than the teacher with educational background ST and S.ST.

- The quality of learning skills, electronics and electricity program in West Java can be shown in Table 3.22 to Table 3:25, resulting in the following order: $\mathrm{S} . \mathrm{Pd}=$ 104.26, S.ST $=101.48, \mathrm{ST}=97.74$.

There is a positive correlation with the score of Pearson correlation of 0.797 at a significance level of 0.01 between the level of professionalism of teachers on the quality of vocational teachers learning skills electronics and electricity. Study Program in West Java. These figures mean that $63.5 \%$ the quality of the learning process is determined by the professionalism of teacher expertise in engineering electronics and electricity in West Java.

\section{References}

[1] Sekretariat Negara. (2003). Undang -Undang Nomor 20 Tahun 2003 tentang Sistem Pendidikan nasional. Jakarta

[2] Sekretariat Negara. (2005). Undang -Undang Nomor 14 Tahun 2005 tentang Guru dan Dosen. Jakarta.

[3] Sekretariat Negara. (2005). Peraturan Pemerintah Republik Indonesia Nomor 19 Tahun 2005 tentang Standar Nasional Pendidikan. Jakarta.

[4] Sekretariat Negara. (2008). Peraturan Pemerintah Republik Indonesia Nomor 74 Tahun 2008 tentang Guru. Jakarta.

[5] Sekretariat Negara. (2000). Keputusan Mentri Pendidikan Nasional Republik Indonesia Nomor 232/U/2000 tentang Pedoman Penyusunann Kurikulum PT dan Penilaian Hasil Belajar Mahasiswa Peserta Didik. Jakarta.

[6] Sekretariat Negara. (2000). Keputusan Mentri Pendidikan Nasional Republik Indonesia Nomor 045/U/2002 tentang Kurikulum Inti PT. Jakarta.

[7] Peter Jarvis. (1983). Profesional Education, Croom Helm Ltd Beckenhum Australia.

[8] Orstein, Alan C. (1992). Strategies for Effective Teaching. New York: Harper Collins Publisher.

[9] (2010). Conference Guide International Conference on Teacher Education "Redesaining Profesional Teacher Education". Bandung: UPI PRESS.

[10] Evans, Ruper N., Herr, Edwin L. (1978). Foundations of Vocational Education, Ohio: Charles E. Merrill Publishing Company.

[11] Gagne, R.M. (1997). The Conditions of Learning. New York: Holt, Rinehart \& Winston.

[12] Wittrock, M.C.(1986). Handbook of Research on Teaching. New York: Macmilla Publishing Company.

[13] Creswell Jhon W. (2009). Research Design Qualitative, Quantitative, and Mixed Methods Approacehes. Third Edition. California: SAGE Publications.

[14] Spottl, Bukit M. (2009). Standarisation in TVET Teacher Education. Lang Publishers, Frankfrut a.M.es. 
[15] Dittrich, J. et al. (2009). Standardisation in TVET Teacher Education. Berlin: Peter Lang.

[16] Baha, Sayed A. (1991). Technical and Vocational Education and Training. Manila: Asian Development Bank.

[17] Diamond, Robert M. (1999). Designing and Improving Courses and Curricula in Higher Education. San Fransisco: Jossey Bass Publlishers.

[18] Lauglo, Jon, Lilis, K. (1988). Vocational Education, Oxford: Pergamon Press. 